\title{
SWOT ANALYSIS OF ENERGY POLICY 2013 OF PAKISTAN
}

Muhammad Irfan', Suleman Abdul Hameed ${ }^{2}$, Umer Bin Sarwar ${ }^{3}$, Naeem Abas ${ }^{4}$, Muhammad Shoaib Saleem ${ }^{5}$

${ }^{1,4}$ Department of Electrical Engineering, University of Gujrat, Hafiz Hayat Campus, Gujrat. naeemkalair@uog.edu.pk

2 Faculty of Electrical Engineering, University of Engineering and Technology Lahore. engr.suleman.grt@gmail.com

3 US Pakistan Center for Advanced Studies in Energy, National University of Science and Technology, Islamabad.-u.sarwar92@gmail.com,

5 Department of Electrical Engineering, University of Management and Technology, Sialkot Campus, Sialkot.muhammad.shoaib@skt.umt.edu.pk.

\section{ARTICLE INFO}

Keywords:
National Power Policy,
SWOT analysis,
Comprehensive, Capacity
building

\begin{abstract}
Pakistan is going through worst energy crisis over a decade. The hide and seek of electricity has threatened lives in all sectors of Pakistan. To cope up with this issue, the National Power Policy 2013 of Pakistan was formulated. The main problems faced by the national energy sector are supply-demand gap, highly expensive generation of electricity from sustainable energy recourses, incompetent power production, transmission and distribution system, power and transmission losses, lack of production of electricity from renewable energy recourses, and misuse of electricity and electricity theft. The Strengths, Weaknesses, Opportunities and Threats (SWOT) of the policy are discussed in this paper. The SWOT analysis of national power policy 2013 gives a better solution to the government regarding current and future energy needs. This paper presents the formulated actions such as comprehensive energy strategy; upgradation of existing transmission and distribution systems; development of indigenous resources and energy mix systems; productions at low price electricity by low price fuels; electricity generation from renewable energy recourses; structural change in industry; subsidies to private sectors generation and compliance with environmental standard. This further enlightens the adoption of institutional and human capacity building by energy sector for the betterment of the country.
\end{abstract}




\section{Introduction}

Energy is the hot line of life at planet earth. Depletion of oil, sustainability, macroclimate modifications and environmental concerns lead towards obligatory energy shift from molecular fossil fuels and atomic reactors towards renewable energy resources (N. Khan, Kalair, Abas, Kalair, \& Kalair, 2018). Talking in the context of environmental effects, alternative refrigerants being green in nature and environmental friendly are encouraged to replace initially CFCs by HCFCs or HFCs provisionally and finally replacing HCFCs or HFC to low GWP and ODP synthetic and natural refrigerants (Abas et al., 2018). The per capita impression of climate revolution on the millions of Pakistanis is very high in comparison to lesser per capita stake of global Greenhouse Gases (GHG) emissions (Abas, Kalair, Khan, \& Kalair, 2017). Harvesting solar energy to meet domestic hot water demand is desired as an substitute design solution (Abas, Khan, Haider, \& Saleem, 2017). Carbon dioxide offers high heat transfer capabilities without damaging environment (Abas \& Khan, 2016). Earth, sun and atmosphere are the ultimate energy resources. In addition to fossil fuels, earth radiates over 45 TW geothermal energy. Sun radiates about $89 \mathrm{PW}$ energy to earth's surface. Lunar gravity supplies over 100 GW tidal ocean energy (Nasrullah Khan, Abas, \& Kalair, 2015). Design of net zero or nearly zero is very promising to reduce reliance on conventional energy resources (M. Irfan, Abas, \& Saleem, 2018). Installation of on-site renewable energy resources including wind and solar for independent generation is getting attention these days in the context of zero-energy homes and buildings (Muhammad Irfan, Abas, \& Saleem, 2018). Power Potential from tidal current stations is more than energy converter (WEC) devices which in turn is more than osmotic, ocean thermal energy conversion (OTEC) and ocean thermoelectric generators (OTEG) technologies (N Khan, Kalair, Abas, \& Haider, 2017).

The aim of national power policy, prepared by the MoWP (Ministry of Water and Power) of 
Pakistan is to support the current and future requirements of energy of country. The main purpose of this strategy is not only to discuss the challenges faced by energy sector but also to keep the country on a path of fast social and economic development (GoP, 2013a). The purpose was to give a lot desired assistance and an improved standard of livelihood to the people of the country. The key targets set by Pakistan are to affordability, demand-supply gap, efficiency, governance of the system and financial viability. The consumption and demand for energy is increasing, this proves that energy will become one of the major problems in future of the world (Rafique \& Rehman, 2017). As energy is a fundamental input for the development and continual financial growth. The living standards of population of a country are evaluated by its energy consumption. The demand for energy has been increasing at a rate higher than the whole primary energy supply due to technological and fast industrial growth in Pakistan (J. Anwar, 2016a). The national government is devoted to exploring all energy sources to resolve the current crisis. If government is funding and using the technologies then the power sector gives the most capable potential of energy (Pakistan's Intended Nationally Determined Contribution, 2016).

As there is a number of energy policies, analyses, development plans and strategies were made but also ignored by the government. The key targets set by government will be fulfilled up to 2017 . The procedure of strategy and policy formulation is clued-up by the subsequent organizing principles: (I) Efficiency (II) Competition (III) Sustainability. The government of Pakistan (GoP) has planned strategies for the mentioned goals to overcome the power crisis of country within the framework of the power policy principles, which are demand supply, supply strategy, affordable power strategy, governance strategy, supply-chain strategy, financial efficiency strategy, generation strategy, transmission and distribution strategy (GoP, 2013b).

In an attempt to look for the growth of renewable energy for power production in Pakistan, an 
internal micro-environmental analysis should be carried out to assess the relevant strengths, weaknesses, opportunities and threats (SWOT) (Zhu, Hiltunen, Antila, Huang, \& Song, 2015). SWOT analysis is widely using strategic planning by different institutions. SWOT analysis sheds lights on the strengths and weaknesses of the existing energy system. It gives us the ideas about the opportunities that the country can be utilized. It also indicates potential threats that are barriers to achieve the goals. The SWOT analysis proposes actions and solutions that can be recommended in the roadmap (Shakeel, Takala, \& Shakeel, 2016).

This paper gives the SWOT analysis of national power policy 2013 of Pakistan. This paper is focused on analyzing the main areas of energy, efficiency, competition and sustainability. This paper also sheds lights on demand supply, supply strategy, affordable power strategy, governance strategy, supply-chain strategy, financial efficiency strategy, generation strategy, transmission and distribution strategy and proposes better solutions for attaining efficiency, competition, sustainable energy development for the betterment of the country. The significance of this paper is that this paper focuses on the strengths, weaknesses, opportunities and threats of national power policy, so government utilizes it as a base and will make the further policies which are more and more helpful to minimize the energy crisis of the country. Transport of energy over long distances from remote natural sources to consumers in big cities requires technical, economic and environmental considerations. Uncertain wind flow, sunshine, faults and communication failures can compromise system safety, reliability, power quality during small signal and large scale power system oscillations. HVAC systems tackle power swing issue by electrical islanding protection schemes which would need to be revised for integrated AC/DC systems (Kalair, Abas, \& Khan, 2016). 


\section{Methodology}

SWOT analysis, a key tool is used in this research paper. This tool gives us the development of energy on national level. For municipal planning regional progress this tool was used in 1980 by the business administration journalism (Bryson \& Roering, 1987; Karppi, Kokkonen, \& Lahteenmaki-Smith, 2001; MEANS Collection - Evaluation of socio-economic programmes, 1999). Many examples are there in which the application of SWOT analysis are used such as in Municipal Solid Management (Srivastava, Kulshreshtha, Mohanty, Pushpangadan, \& Singh, 2005) and in Regional Energy Planning (Terrados, Almonacid, \& Hontoria, 2007). The European states also utilized the SWOT analysis in their policies making and in many national strategies for their continual progress (European Commission, 2004). There are four components of the SWOT (Strengths, Weaknesses, Opportunities and Threat). Two of the components of SWOT (Strengths and Weaknesses) are explained the signs of the inner circumstances and the other two components (Opportunities and Threats) explained the signs of the outer environment (Dealtry, 1992). This paper studies strength builds up, remove weaknesses, utilize opportunities and lessen consequence of threats of national power policy 2013 of Pakistan. The components of SWOT analysis are shown in figure 1.

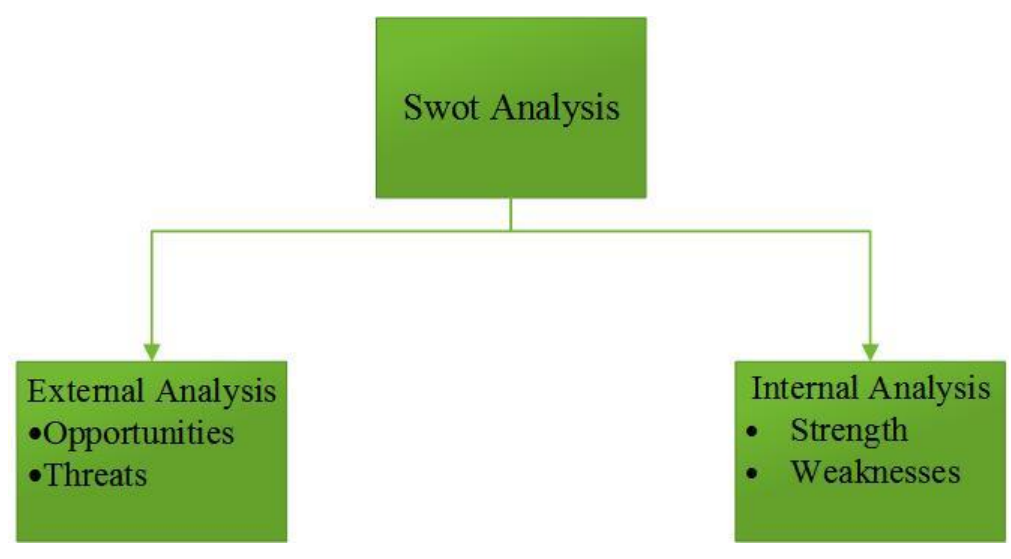

Figure 1: Components of SWOT 
Modern techniques can be used to explore the SWOT analysis of national power policy such as seminars in collaboration and participation of the energy stakeholders, regulatory authority, related ministries, energy consumers such as small and large industries, local governments, private sectors, foreign funding institutions, generation and distribution (oil and gas), operators (electricity production, distribution, transmission), public and media. In one seminar the components of SWOT should be discussed. In other seminar the existing energy system, what we want and how we will achieve it. The results of the SWOT analysis also should be discussed.

\section{Review of Policy}

A review of the national power policy 2013 is shown in figure 2. This describes the challenges, goals, targets and how can we achieve these goals and targets.

\begin{tabular}{|c|c|c|}
\hline Challenges & Goals and Targets & $\begin{array}{c}\text { How to achieve goals } \\
\text { and targets? }\end{array}$ \\
\hline $\begin{array}{l}\text { - Demand-supply gap } \\
\text { - High expensive } \\
\text { generation of } \\
\text { electricity } \\
\text { - Inefficient power } \\
\text { transmission and } \\
\text { distribution system } \\
\text { - T \& D losses } \\
\text { - Poor infrastructure } \\
\text { - Theft of electricity } \\
\text { - High per unit } \\
\text { delivering cost to } \\
\text { customers } \\
\text { - Debilitating levels of } \\
\text { subsidies } \\
\text { - Circular debt. }\end{array}$ & $\begin{array}{l}\text { - Build power generation } \\
\text { capacity } \\
\text { - Decrease supply } \\
\text { demand gap } \\
\text { - Culture of energy } \\
\text { conservation } \\
\text { - Generate electricity } \\
\text { from Thar coal and } \\
\text { Hydel } \\
\text { - Minimize pilferage and } \\
\text { adulteration in fuel } \\
\text { supply } \\
\text { - Decrease cost of } \\
\text { generation } \\
\text { - Promote world class } \\
\text { efficiency } \\
\text { - Create cutting edge } \\
\text { transmission network } \\
\text { - Decrease T \& D losses. } \\
\text { - Financial viability } \\
\text { - Decrease decision } \\
\text { making time by related } \\
\text { authorities. }\end{array}$ & $\begin{array}{l}\text { - Use of energy mix } \\
\text { - Instem } \\
\text { capacity } \\
\text { - Generate } \\
\text { electricity from } \\
\text { renewable } \\
\text { resources } \\
\text { - Improving the } \\
\text { transmission and } \\
\text { distribution } \\
\text { infrastructure } \\
\text { - Reforming } \\
\text { subsidies and } \\
\text { support schemes } \\
\text { - Maintaining the all } \\
\text { systems very well } \\
\text { - Awareness to the } \\
\text { people the } \\
\text { importance of the } \\
\text { energy }\end{array}$ \\
\hline
\end{tabular}

Figure 2: Review of National Power Policy 2013 


\subsection{Economic growth of Pakistan}

National power policy 2013 will set the Pakistan on the path of social and economic growth. Total energy supply in 1995 of Pakistan was 28 million tons of oil equivalent (MTOE) which increased up to 64588 thousands TOE. The energy consumption in 2013 was 40185 million tons of oil equivalents (MTOE). Following figure 3 shows the trend of energy supply by resources.

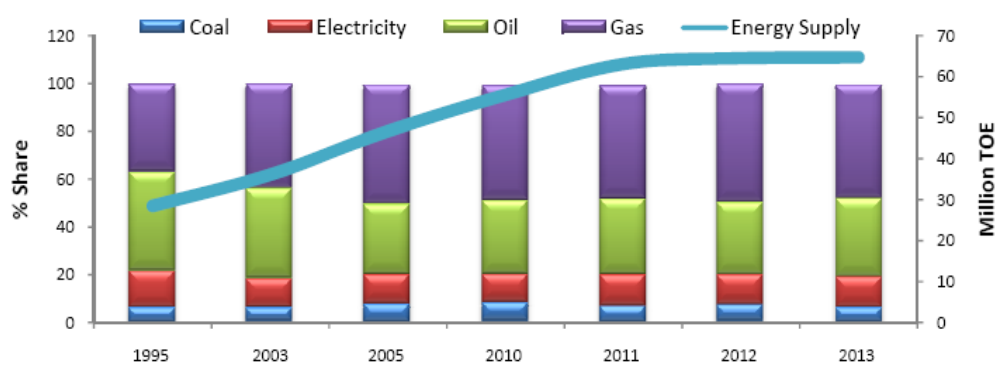

Figure 3: Primary energy supply by source of 1995-2013 (Pakistan Economic Survey 2013, n.d.-

a)

Oil is an efficient and primary source of energy supplies, its share to generate electricity decreased by $32.5 \%$ but share of gas raised $48.2 \%$ because the price of oil worldwide increased. The growth rate GDP of Pakistan increased to 4.14\% in 2013 from the previous year. This increase in GDP clearly shows that the policies of Govt. are very fruitful (Pakistan Economic Survey 2013, n.d.-b). Increase in GDP means that policy gives the fruitful results.

\section{Swot Analysis of Policy}

The components of SWOT (Strengths, Weaknesses, Opportunities and Threat) are shown in figure 


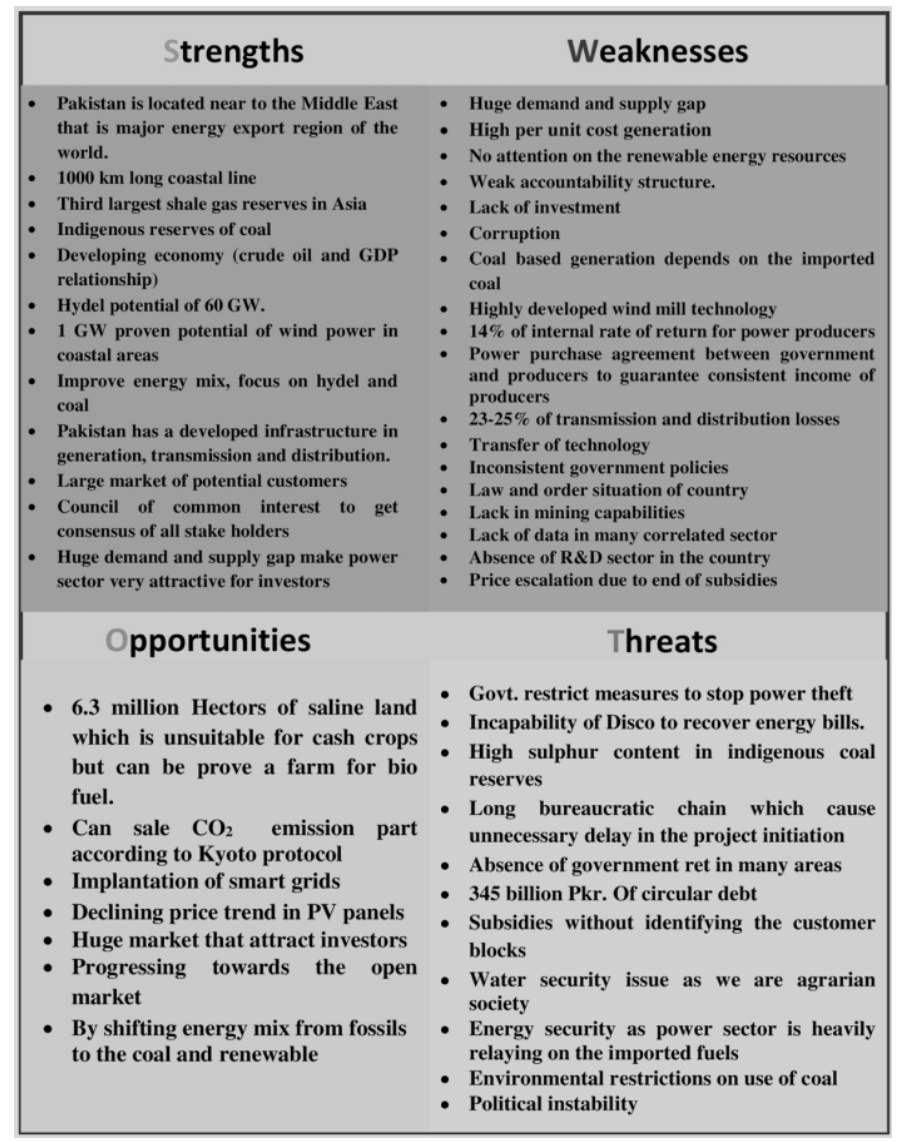

Figure 4: SWOT Analysis

\subsection{Strengths}

The strengths of the national power policy 2013 of Pakistan are as follows.

\subsubsection{Pakistan's Geological position}

Pakistan is located in central Asia. It shares border with China, India, Iran, Afghanistan and Arabian Sea in the Northwest, East, Southwest, West and South respectively. Pakistan's geographic location is a good strength that it attracts the other countries in the search of their energy, economic and political interests. Pakistan links central Asian and Middle East. Pakistan is facilitating the Afghanistan, central Asian countries and the other neighboring countries by providing them transportation route and easier access to Arabian Sea for trading gas and oil (Z. Anwar, 2011). The sea port Gwadar is also strength for Pakistan because it has land access to the 
Iran. Iran wants to build oil refinery in Gwadar to attain the more of its shares in the global oil markets through it. Gwadar is located at the mouth of Persian Gulf, third busiest route which is treating $43 \%$ oil trade of Chinese $35 \%$ of international sea borne (Shaikh, Ji, \& Fan, 2016). As stated in the policy that Pakistan is located near to the Middle East that is major energy export region of the world and has $1000 \mathrm{~km}$ long coastal line. So these are great strengths for Pakistan to have more and more energy.

\subsubsection{Conventional, non-conventional energy resources}

The consumption of electricity in Pakistan is growing day by day at the rate of 7 from the last 25 years but the installation capacity is not improved by the power sector due to insufficient investment. The energy demand increased from 10459MW to 18827MW from 2001 to 2013, while energy supply increased only $2 \%$ for the same period up to $13577 \mathrm{MW}$ only. The demand energy gap was of 5000MW in 2013 results 12 to 16 hours per day of load shedding (M. A. Khan \& Abbas, 2016).

In 2013 the primary energy supply was 64.5 MTOE. The dependence of Pakistan on thermal electricity was $87 \%$, hydel $11 \%$ and on nuclear power $1.7 \%$. The main sources were Gas 31.1 MTOE, Oil 20.96 MTOE, Coal 3.8 MTOE, LPG 0.3 MTOE, Hydroelectricity 7.1 MTOE, Nuclear electricity 1 MTOE and imported energy 0.08 MTOE with shares. The percentage contribution in producing the electricity was $48.2 \%, 32.5 \%, 11 \%, 6 \%, 1.7 \%, 0.5 \%$ and $0.1 \%$ by gas, oil, hydro, coal, nuclear, Liquid Pressurized Gas (LPG) and imported energy respectively. Pakistan has a huge potential of renewable energy resources other than the non-renewable energy resources. In current energy generation scenario less than $1 \%$ energy is produced from these resources while solar has a potential of $2900000 \mathrm{MW}$, wind has 34600MW, biogas has 3000MW, small hydel power has 2000MW and waste materials energy has 1000MW (Wakeel, Chen, \& Jahangir, 2016). Pakistan 
can generate the electricity from coal, gas, hydel and wind as stated in the power policy and they have a huge potential to produce electricity. According to policy Pakistan has indigenous reserves of coal, crude oil , hydel potential of $60 \mathrm{GW}, 1 \mathrm{GW}$ proven potential of wind power in coastal areas and third largest shale gas reserves in Asia. Low cost energy is produced by changing the fuel mix towards fewer costly fuels. Low cost fuel mix will give the cheap electricity by the investors (GoP, 2013b).

\subsubsection{Potential customers and stakeholders}

The other strength of Pakistan is its investors to generate electricity and customers to buy this energy which ultimately give profit to the government. As Pakistan has;

- Huge demand and supply gap make power sector very attractive for investors

- Large market of potential customers

- Council of common interest to get consensus of all stake holders

The government has some new business models which allow the generation companies to sell their electricity to private sectors, DISCOs and NTDC. If these models are implemented successfully then due to these models the price of electricity will be reduced. NEPRA and world-class regulatory are encouraging the investors to generate electricity and controlling Competitive Bidding process and Tariff which will set the cost of fuel and electricity (GoP, 2013b).

\subsection{Weaknesses}

The weaknesses of the power policy 2013 are discussed as follow. If government eliminates the following weaknesses then it should be able to meet its goals easily.

\subsection{Huge demand and supply gap}

The main focus of the power policy is demand-supply gap. According to policy the demand-energy gap was 4500 - 5500 MW in 2013. The governments should remove this gap for the betterment 
of the country. The important steps are taken by the government for uninterruptable and smooth energy supply to the people is upgrading the transmission system and reduces the circular debt on priority. The government should give priority to hydro production because cost of hydrogenation is very economical and also abundantly its source is available (Shakeel et al., 2016). Power quality problems are manifested in voltage, current or frequency deviations causing malfunction of sensitive equipment. Integration of inverter connected PV and wind power plants, and rampant rise in nonlinear loads have led to harmonic problem in power system. Nonlinear loads and switched devices energized by sinusoidal sources or linear loads and switched devices with nonsinusoidal sources, produce harmonics in distribution system (Kalair, Abas, Kalair, Saleem, \& Khan, 2017).

\subsubsection{High per unit cost generation}

Most of the demand of electricity is fulfilled by expensive thermal fuels sources due to which the price of electricity generation is very high about Rs. 12 / unit. The biggest electricity generation sources are Residual fuel oil ( Rs 17 / unit), High Speed Diesel ( Rs 23 / unit) and Mixed ( Rs 12 / unit). The population of Pakistan cannot afford these prices of electricity. The solution of this weakness is that government should generate cheap electricity from hydro, solar, wind etc.

\subsubsection{Under develop infrastructure}

In the progress of economy of Pakistan he power sector plays a vital role. But due to inefficient system, high losses, mismanagement and insufficient infrastructure the power sector is under developed (M. A. Khan \& Ahmad, 2008). Pakistan has a developed infrastructure in generation, transmission and distribution. For the achievement of medium and long term goals of power policy the government must develop the infrastructure and give incentives to the investors. As Pakistan has a huge quantity of coal and potential for hydel power generation, so government will give the 
foundations of corridors and energy cities and attract the investors for their installations. A "key client managers or relationship managers" is allocated by the government at Ministry of Water and Power which will perform as a 'one window operation' and check and balance for the investors to ensure the completion of projects timely.

\subsubsection{No attention on the renewable energy resources}

The government has no attention on the renewable energy resources accept hydel and wind. The total potential of renewable energy resources is of capacity of $167.7 \mathrm{GW}$, which encourages the government to produce electricity from these resources because this potential is more than enough for the generation of electricity to eliminate the demand-supply gap of the country. Only following power plants produces the electricity of a few capacities as described in the table 1, which is not enough as compared to the potential of all renewable energy resources.

Table 1 Generation from renewable energy resources in Pakistan (Rafique \& Rehman, 2017)

\begin{tabular}{|c|c|c|}
\hline Installed & Units & Total capacity \\
\hline Micro-hydel & 538 & $7.8 \mathrm{MW}$ \\
\hline Wind turbine & 155 & $161 \mathrm{MW}$ \\
\hline Solar PV & 300 & $100 \mathrm{~kW}$ \\
\hline Biogas plant & 4,000 & $1,800 \mathrm{~m} 3 /$ day \\
\hline Solar dryer & 21 & $5,230 \mathrm{~kg} /$ day fruit \\
\hline
\end{tabular}

\subsubsection{Unsatisfactory human and institutional capacities}

The main problems of the energy sector due to a huge demand-supply gap presents are as follows; 
- Weak accountability structure.

- $\quad$ Lack of investment

- Corruption

- Transfer of technology

- Inconsistent government policies

- Law and order situation of country

- $\quad$ Lack in mining capabilities

- Lack of data in many correlated sector

- $\quad$ Absence of R\&D sector in the country

To eliminate the weaknesses the government should makes some affective policies which should be followed by the govt., human beings and all the institutions.

\subsection{5 $\quad T \& D$ losses}

There are $23-25 \%$ of transmission and distribution losses mentioned in the policy. T \& D losses decrease the efficiency of the system. These losses should be removed to improve the efficiency of system and upgrade the T \& D system. The government of Pakistan, like other developed countries e.g. US and China should implement new technologies for the reduction of these losses. These new technologies include gas insulated substation, HVDC and advance metering which may take part in the development of the country (Bhatti et al., 2015). Due to T \& D losses the revenue should not be increase. If government brings these losses down the revenue collection should increase and this investment utilizes in up gradation of system, makes new generation plants and develops the transmission infrastructure . 


\subsubsection{No attention on coal reserves}

The electricity generates in Pakistan by coal depends upon the imported coal which is a large weakness and failure of government. Pakistan produces only $0.79 \%$ of electricity from coal but Pakistan stands at $7^{\text {th }}$ number in ranking of coal according to the research, so Pakistan can generate a high amount of electricity from coal. Coal plays a vital role to produce electricity because the energy demand is increasing continuously. The generation of electricity from coal is improved from $0.79 \%$ to $6.5 \%-7.6 \%$ (2003 to 2011 ) because Pakistan has a potential of $100000 \mathrm{MW}$ of capacity of electricity from coal (Latif \& Ramzan, 2014).

\subsubsection{Problems facing by power producers}

One of the reasons of huge demand-supply gap of electricity in Pakistan is that government does not attract the investors by giving them any subsidy or reduce the rate of return. The problems face by the power producers are as follows;

- $14 \%$ of internal rate of return for power producers.

- Power purchase agreement between government and producers to guarantee consistent income of producers.

- Price escalation due to end of subsidies.

To eliminate the load shedding the government should facilitate the power producers in any manner from the above problems.

\subsection{Opportunities}

The opportunities for our energy sector are discussed below. If government utilizes the following opportunities then we can fulfill our energy demands. 


\subsubsection{Availability of saline land}

As stated in policy that 6.3 million hectors of saline land which is unsuitable for cash crops but can be prove a farm for bio fuel. The prices of oil and diesel are increasing due to their shortage and production of electricity from them. Use of biofuels for energy production is money saving, attraction for the investors, reduction in the discharge of gases in environment and having same properties like fossil fuels. Due to the above reasons the biofuels are best to produce electricity (Rozina, Asif, Ahmad, Zafar, \& Ali, 2017). Pakistan has an agricultural land with 22.2 million ha of cropped region. This land produces million tons of biomass (cotton sticks, wheat straw, maize stalks, sugarcane trashes and bagasse, rice husk and paddy etc) per annum. From this residue Pakistan produces 81 million tons annually which can generate 45,870 million kWh of electricity yearly (Ghafoor, Rehman, Munir, Ahmad, \& Iqbal, 2016). According to under Pakistan's Energy Security Action Plan (2005-2030) the energy production from biomass will feed 4000MW of electricity to national grid and save USD 200 to 400 million (Rehman, Rashid, Saif, Mahmood, \& Han, 2013).

\subsubsection{Availability of LPG}

In energy supply mix the contribution of LPG is less than $1 \%$ while it is produced 1000 of tons in a day. LPG is only used as a conventional fuel for cooking instead of firewood, coal, dung cake or kerosene for cooking purpose where connections of natural gas are unavailable (Ministry of Petroleum \& Natural Resources, Liquefied Petroleum Gas (Production \& Distribution) Policy Guidelines, 2013). It is a great opportunity for the Pakistan to produce electricity from the LPG as it has a great potential of it. 


\subsubsection{Declining price trend in PV panels}

It is a great opportunity for Pakistan's government, investors and population to produce electricity from the solar system because there is no fuel cost to generate such cost of energy. The prices of solar modules were reduced to $75 \%$ in 2009 . The costs of their installation have decreased from 2010 to 2014 depending on regions ranges between $29 \%$ to $65 \%$ for utility scale systems. The price per unit is only $\$ 0.08$ of delivering of electricity from these power plants. The prices of solar photovoltaic modules are very low and having great potential of solar may reduce the finance costs of the power plants (Renewable Power Generation Costs in 2014., 2015).

\subsubsection{Implantation of smart grids}

Another opportunity for Pakistan is the implementation of smart grids for the betterment of country. As there are complications in grid management and high demand of energy, the existing grids are not suitable for generation and distribution systems. So very efficient, self regulating and reliable grid stations (smart grids) are required for such developments. To handle energy crisis this new technology is required because it has a lot of opportunities (Muhammad Irfan et al., 2017).

\subsubsection{Huge market for investors}

Pakistan is running short of electricity so it has a huge market that attracts investors and is progressing towards the open market. Pakistan has a number of strengths and opportunities to produce electricity from different sources like renewable energy resources, coal and LPG which may be the source of attraction for the investors.

\subsubsection{Energy mix (Use of coal, hydropower and renewable energy resources)}

Pakistan is very rich in coal at Tharparkar having 175 to 185 trillion tones which can generate 100 million barrels oil for 500 years and 50000MW of electricity for decades. These resources can produce cheap electricity and give strengths to economic growth of the country (Satti, Hassan, 
Mahmood, \& Shahbaz, 2014). Also Pakistan has a potential of 100GW of hydropower, $2900 \mathrm{GW}$ of solar, $120 \mathrm{GW}$ of wind and $5.7 \mathrm{GW}$ of biomass. Hydropower generation is very cheapest source of electricity and also can use for agricultures (Farooqui, 2014). Electricity from above mentioned resources can reduce its dependence upon fossils fuels. A balanced energy mix resources are used for future energy demands.

\subsection{Threats}

The last component of the SWOT analysis is threat. For national power policy 2013 the threats are as follows;

\subsection{Power theft and recovery of bills}

The loss due to the theft of electricity is above the Rs. 140 billion per annum. It may a huge financial loss to the government and has a bad impact on the investors. The theft of the electricity and not payment of bills are big crimes in every country especially in Pakistan. Measures should be taken by;

- Govt. restrict measures to stop power theft

- DISCO are capable to recover energy bills.

The overall solution of these two problems or threats is to take some technical measures.

The theft of electricity, physical damage of energy meters and indiscretion in payment of bills cause financial losses above than $\$ 89$ billion annually in the overall world. These losses are tackled by the implementation of smart meters. These meters are especially designed to prevent from theft of electricity, to monitor and for managing the energy automatically (Hussain, Memon, Zardari, Shah, \& Z. A. Bhutto, 2015). 


\subsubsection{Circular debt}

Pakistan has Rs. 345 billion of circular debt. The inefficient systems, power losses, theft of electricity, unpaid billings and high cost of energy generation increase the circular debt of the country. By controlling all of the losses and mismanagements, any government can control its circular debt.

\subsubsection{Security issue}

The two threats are also as follows;

- Water security issue as we are agrarian society

- Energy security as power sector is heavily relaying on the imported fuels

Our agricultural sector uses the water at free of cost, annually consumes about $91.6 \%$ of the water of the country ("Water Security: Pakistan's most Critical Development Challenge," 2017). As our country is an agricultural country, according to the UN reports in future the water in our country will be insufficient for us (Iqbal, 2010). We are relying on the imported fuel to generate electricity, so imported fuel is a major issue of energy security. Pakistan's economy is poor due to which it is difficult for Pakistan to afford the imported fuel for generation of electricity at huge level. This dependence of generation on imported fossil fuels gives exposure to the energy security of the country. Also these fuels pollute the environment of the country. According to Energy Security Action Plan (2005-2030), "a target of 162,590MW of power generation by 2030 was projected. This comprehensive energy security action plan is expected to fulfill the energy requirement of Pakistan economy and enhance energy security of the country" (J. Anwar, 2016b).

\subsubsection{Environmental restrictions on use of coal}

At present Pakistan is totally relying on the energy produced by fossils which may a big threat to the environment. Pakistan is rich in coal reserves. If we will rely on coal for the generation of 
electricity then we facing the severe threats to our environment. There is high sulphur content in indigenous coal reserves and also there are environmental restrictions on use of coal. Again best option is to produce electricity from renewable energy resources. Although the focus of all the power generation policies on the production of electricity from indigenous renewable energy which can control on the environmental emission (J. Anwar, 2016b).

\subsubsection{Political instability and Long bureaucratic chain}

It is also a big threat to the energy sector of Pakistan that Pakistan is politically unstable. Pakistan is unable to stable politically due to many reasons. These reasons may be the social growth, economic growth and unstable democratic system. Another threat is long bureaucratic chain in Pakistan for the approval of any system in the country. The long bureaucratic chain causes unnecessary delay in the project initiation.

\subsubsection{Unnecessary subsidies}

The main requirements of our country regarding power sector are to manage the existing system, to control losses and to upgrade the generation and distribution systems. Otherwise another option is to give subsidies to departments to overcome the problems. The government is giving subsidies without identifying the customer blocks which may cause to increase the circular debt of the country.

\section{Conclusions}

The SWOT analysis of Pakistan's energy sector has been presented keeping in view the national power policy 2013 of Pakistan which may be helpful for the energy sector of Pakistan to know its strengths, weaknesses, opportunities and threats. The paper presents the challenges, goals and targets of power policy and their solutions. The paper is an effort to provide a futuristic solution of energy issues for the government. Through this analysis the government will be able to 
understand current and future needs of energy of Pakistan; how to make energy cost effective, from which sources it is better to generate electricity, which source is environmental friendly, which source is easily available, how to control transmission and distribution losses, how to manage the generation and transmission systems and how theft of electricity be controlled. The analysis highlights the importance of energy strategy, the change of energy mix system from fossil fuels to coal as well as renewable energy resources and implementation of smart grids. Considering and implementing the ideas presented in this paper can surely bring Pakistan on the track of energy prosperity.

\section{REFERENCES}

Abas, N., Kalair, A., Khan, N., \& Kalair, A. R. (2017). Review of GHG emissions in Pakistan compared to SAARC countries. Renewable and Sustainable Energy Reviews, 80, 990-1016. https://doi.org/10.1016/j.rser.2017.04.022

Abas, N., Kalair, A. R., Khan, N., Haider, A., Saleem, Z., \& Saleem, M. S. (2018). Natural and synthetic refrigerants, global warming: A review. Renewable and Sustainable Energy Reviews, 90. https://doi.org/10.1016/j.rser.2018.03.099

Abas, N., \& Khan, N. (2016). A Thermosyphon driven Solar Water Heater Using CO 2 as Working Fluid. Journal of Applied Environmental and Biological Sciences, 6, 43-54.

Abas, N., Khan, N., Haider, A., \& Saleem, M. S. (2017). A thermosyphon solar water heating system for sub zero temperature areas. Cold Regions Science and Technology, 143, 81-92. https://doi.org/10.1016/j.coldregions.2017.08.012

Anwar, J. (2016a). Analysis of energy security, environmental emission and fuel import costs under energy import reduction targets: A case of Pakistan. Renewable and Sustainable Energy Reviews, 65, 1065-1078. https://doi.org/10.1016/j.rser.2016.07.037 
Anwar, J. (2016b). Analysis of energy security, environmental emission and fuel import costs under energy import reduction targets: A case of Pakistan. Renewable and Sustainable Energy Reviews, 65, 1065-1078. https://doi.org/10.1016/j.rser.2016.07.037

Anwar, Z. (2011). Development of Infrastructural Linkages between Pakistan and Central Asia. South Asia Journal of South Asian Studies, 26(1), 103-11.

Bhatti, S. S., Lodhi, E. M. U. U., Shan-ul-Haq, Engr. S. N. M. Gardezi, E. M. A. J., Raza, E. M. Z., \& Lodhi, E. M. I. U. (2015). Electric Power Transmission and Distribution Losses Overview and Minimization in Pakistan. International Journal of Scientific \& Engineering Research, 6(4).

Bryson, J. M., \& Roering, W. D. (1987). Applying Private-Sector Strategic Planning in the Public Sector. Journal of the American Planning Association, 53(1), 9-22. https://doi.org/10.1080/01944368708976631

Dealtry, T. R. (1992). Dynamic SWOT analysis: developer's guide. Birminghum.

European Commission. (2004). National sustainable development strategies in the European Union: a first analysis by the European Commission,.

Farooqui, S. Z. (2014). Prospects of renewables penetration in the energy mix of Pakistan. Renewable and Sustainable Energy Reviews, 29, 693-700. https://doi.org/10.1016/j.rser.2013.08.083

Ghafoor, A., Rehman, T. ur, Munir, A., Ahmad, M., \& Iqbal, M. (2016). Current status and overview of renewable energy potential in Pakistan for continuous energy sustainability. Renewable and Sustainable Energy Reviews, 60, 1332-1342.

https://doi.org/10.1016/j.rser.2016.03.020

GoP. (2013a). National Power Policy 2013. Retrieved from http://www.ppib.gov.pk/National 
Power Policy 2013.pdf

GoP. (2013b). National Power Policy 2013.

Hussain, Z., Memon, S., Zardari, S., Shah, R. H., \& Z. A. Bhutto. (2015). Systematic Analysis of Smart Meter Technologies and Their Implementation Challenges in Pakistan. Oral Science International, 28(4), 113-120.

Iqbal, A. R. (2010). Water Shortage in Pakistan - A Crisis Around the Corner. Institute for Strategic Studies, Research \& Analysis, 2(2).

Irfan, M., Abas, N., \& Saleem, M. S. (2018). Net Zero Energy Buildings (NZEB): A Case Study of Net Zero Energy Home in Pakistan. In Power Generation Systems and Renewable Energy Technologies. Islamabad, Pakistan: IEEE.

Irfan, M., Abas, N., \& Saleem, M. S. (2018). Thermal performance analysis of net zero energy home for sub zero temperature areas. Case Studies in Thermal Engineering, 12, 789-796. https://doi.org/10.1016/j.csite.2018.10.008

Irfan, M., Iqbal, J., Iqbal, A., Iqbal, Z., Riaz, R. A., \& Mehmood, A. (2017). Opportunities and challenges in control of smart grids - Pakistani perspective. Renewable and Sustainable Energy Reviews, 71, 652-674. https://doi.org/10.1016/j.rser.2016.12.095

Kalair, A., Abas, N., Kalair, A. R., Saleem, Z., \& Khan, N. (2017). Review of harmonic analysis, modeling and mitigation techniques. Renewable and Sustainable Energy Reviews, 78, 1152-1187. https://doi.org/10.1016/j.rser.2017.04.121

Kalair, A., Abas, N., \& Khan, N. (2016). Comparative study of HVAC and HVDC transmission systems. Renewable and Sustainable Energy Reviews, 59, 1653-1675. https://doi.org/10.1016/j.rser.2015.12.288

Karppi, I., Kokkonen, M., \& Lahteenmaki-Smith, K. (2001). SWOT-analysis as a basis for 
regional strategies. Nordregio.

Khan, M. A., \& Abbas, F. (2016). The dynamics of electricity demand in Pakistan: A panel cointegration analysis. Renewable and Sustainable Energy Reviews, 65, 1159-1178. https://doi.org/10.1016/j.rser.2016.06.054

Khan, M. A., \& Ahmad, U. (2008). Energy demand in Pakistan: a disaggregate analysis. The Pakistan Development Review, 47(4), 437-55.

Khan, N., Abas, N., \& Kalair, A. (2015). Earthy, solaris and atmospheric energy sources. International Journal of Renewable Energy Technology, 6(1), 49. https://doi.org/10.1504/IJRET.2015.067515

Khan, N., Kalair, A., Abas, N., \& Haider, A. (2017). Review of ocean tidal, wave and thermal energy technologies. Renewable and Sustainable Energy Reviews. https://doi.org/10.1016/j.rser.2017.01.079

Khan, N., Kalair, E., Abas, N., Kalair, A. R., \& Kalair, A. (2018). Energy transition from molecules to atoms and photons. Engineering Science and Technology, an International Journal. https://doi.org/10.1016/j.jestch.2018.05.002

Latif, A., \& Ramzan, N. (2014). A Review of Renewable Energy Resources in Pakistan. Journal of Global Innovations in Agricultural and Social Sciences, 2(3), 127-132. https://doi.org/10.17957/JGIASS/2.3.593

MEANS Collection - Evaluation of socio-economic programmes. (1999). Retrieved from https://ec.europa.eu/regional_policy/sources/docgener/evaluation/means_en.htm Ministry of Petroleum \& Natural Resources, Liquefied Petroleum Gas (Production \& Distribution) Policy Guidelines. (2013).

Pakistan's Intended Nationally Determined Contribution. (2016). Retrieved from 
https://www4.unfccc.int/sites/ndcstaging/PublishedDocuments/Pakistan First/Pak-INDC.pdf

Pakistan Economic Survey 2013. (n.d.-a). Retrieved from

http://www.finance.gov.pk/survey_1314.html

Pakistan Economic Survey 2013. (n.d.-b).

Rafique, M. M., \& Rehman, S. (2017). National energy scenario of Pakistan - Current status, future alternatives, and institutional infrastructure: An overview. Renewable and Sustainable Energy Reviews, 69, 156-167. https://doi.org/10.1016/j.rser.2016.11.057

Rehman, M. S. U., Rashid, N., Saif, A., Mahmood, T., \& Han, J.-I. (2013). Potential of bioenergy production from industrial hemp (Cannabis sativa): Pakistan perspective. Renewable and Sustainable Energy Reviews, 18, 154-164.

https://doi.org/10.1016/j.rser.2012.10.019

Renewable Power Generation Costs in 2014. (2015).

Rozina, Asif, S., Ahmad, M., Zafar, M., \& Ali, N. (2017). Prospects and potential of fatty acid methyl esters of some non-edible seed oils for use as biodiesel in Pakistan. Renewable and Sustainable Energy Reviews, 74, 687-702. https://doi.org/10.1016/j.rser.2017.02.036

Satti, S. L., Hassan, M. S., Mahmood, H., \& Shahbaz, M. (2014). Coal consumption: An alternate energy resource to fuel economic growth in Pakistan. Economic Modelling, 36, 282-287. https://doi.org/10.1016/j.econmod.2013.09.046

Shaikh, F., Ji, Q., \& Fan, Y. (2016). Prospects of Pakistan-China Energy and Economic Corridor. Renewable and Sustainable Energy Reviews, 59, 253-263. https://doi.org/10.1016/j.rser.2015.12.361

Shakeel, S. R., Takala, J., \& Shakeel, W. (2016). Renewable energy sources in power generation in Pakistan. Renewable and Sustainable Energy Reviews, 64, 421-434. 
https://doi.org/10.1016/j.rser.2016.06.016

Srivastava, P. K., Kulshreshtha, K., Mohanty, C. S., Pushpangadan, P., \& Singh, A. (2005). Stakeholder-based SWOT analysis for successful municipal solid waste management in Lucknow, India. Waste Management, 25(5), 531-7.

Terrados, J., Almonacid, G., \& Hontoria, L. (2007). Regional energy planning through SWOT analysis and strategic planning tools. Renewable and Sustainable Energy Reviews, 11(6), 1275-1287. https://doi.org/10.1016/j.rser.2005.08.003

Wakeel, M., Chen, B., \& Jahangir, S. (2016). Overview of Energy Portfolio in Pakistan. Energy Procedia, 88, 71-75. https://doi.org/10.1016/j.egypro.2016.06.024

Water Security: Pakistan's most Critical Development Challenge. (2017). Development Advocate Pakistan, 3(4).

Zhu, L., Hiltunen, E., Antila, E., Huang, F., \& Song, L. (2015). Investigation of China's bioenergy industry development modes based on a SWOT-PEST model. International Journal of Sustainable Energy, 34(8), 552-559. https://doi.org/10.1080/14786451.2014.884096 